\title{
On Being Fair to Viktor Shklovsky or the Act of Hedged Surrender
}

Few will cleny that Viktor Shklovsky is an interesting and important enough figure to warrant a close and sympathetic reconsideration. It is equally obvious that no one among us is better equipped, or more strongly motivated, to provide it than is Richard Sheldon. Yet to say that the strentously charitable interpretation of Shklovsky's career which he offers in the March 1975 issue of Slavic Reviczo ${ }^{1}$ is both legitimate and welcome is not necessarily to imply that it is entirely persuasive. Having pondered Professor Sheldon's amply documented brief, I an inclined to qualify or amend some of the judgments made over twenty years ago but not to revise substantially my original view of Shklovsky's vicissitudes, a view, I submit, which is considerably more modulated than Sheldon is prepared to allow.

Let me start with the least important matter. Professor Sheldon maintains that my Russian Formalism "downgrades Shklovsky's role as a founder of the movement and leaves the impression that the Moscow Linguistic Circle actually precedes Opoiaz." Allegedly this misconception "results mainly from the fact that Professor Erlich never mentions in his text even the title of Shklovsky's booklet Resurrection of the Word (1914)" whose publication attracted the attention of such innovative young linguists as $\mathrm{L}$. Iakubinskii and E. Polivanov and thus spurred the formation of Opoiaz. We are told further that "nearly every treatment of Formalism has recognized that booklet as a cornerstone of the movement."'2

As Professor Sheldon notes himself, I did mention the Resurrection of the $W$ ord in my dissertation, without, however, attaching to this brochure as crucial an importance as he does. In revising ny thesis for publication, I deleted a number of passages which at the time I did not consider absolutely germane to its subject. In retrospect, I would have been well advised to spare

1. Richard Sheldon, "Viktor Shklovsky and The Device of Ostensible Surrender," Slavic Review, 34, no. 1 (March 1975): 86-108.

2. Ibid., p. 89, n. 11. 
some of these sections, including the reference to Shklovsky's critical debut: the essay was a seminal if a somewhat muddled performance and it did anticipate some of the essential Formalist concepts. Whether it can properly be described as "the cornerstone of the movement" is something else again. Nor are the authorities arrayed by Professor Sheldon as unanimous on this point as he suggests: if $\mathrm{P}$. Medvedev calls The Resurrection of the Word "the first manifesto of Russian Formalism," B. Eikhenbaum assigns that status unequivocally to Shklovsky's 1919 essay Art as a Device; and V. Markov, whose main concern is with the impact of Shklovsky's lecture-essay on his fellow Futurists, sees in it a harbinger of Russian Futurism's alliance with the "Formalist School of criticism and philology, one of whose leaders Shklovsky was later to become."

As for the relative chronology of the two Formalist centers, assigning precise dates of birth to movements spawned by intellectual bull sessions is chancy business. Presumably Mr. Sheldon knows on good authority that the Opoiaz meetings actually began in 1914. Printed sources that were available to me, including three retrospective accounts by Shklovsky himself, are far from conclusive on that score. No date is assigned to the homely beginnings of Opoiaz in Third Factory (1926), where they are fondly recalled as "evenings at the Briks." In his most recent autobiography, Zhili-byli, Shklovsky is rather vague: "Opoiaz emerged still during the War, before the Revolution." 4 Thus, all I am willing to grant is that I would have been on safer ground had I stated, as Krystyna Pomorska did some years later, that "the Opoiaz group . . began its official activity [italics mine] in 1916."5 (Reference here is to the first joint Formalist publication, Sborniki po teorii poeticheskogo iazyka.) Moreover, in dealing with convergent, and nearly simultaneous intellectual developments, chronological priority is essentially a pseudoissue. What does matter is that neither the preeminence of Opoiazby the time the Formalist movement actually got off the ground-nor the centrality of Shklovsky's role in "organizing and making articulate the methodological ferment in the Russian literary studies" are ever called into question in my book. "In the first years of Opoiaz," I wrote, "he [Shklovsky] made by his articles and speeches a stronger impact on the position and strategy of the movement than any of its spokesmen, with the possible ex-

3. See Pavel Nikolaevich Medvedev, Formal'nyi metod $v$ litcraturovedenii (Leningrad, 1928); "Teoriia 'formal'nogo metoda,'" in Boris Eikhenbaum, Litcratura: Teoriia, kritika, polemika (Leningrad, 1927), pp. 116-48; and Vladimir Markov, Russian Futurism: $A$ History' (Berkeley, 1968).

4. Znamia, 1961, no. 10, p. 188.

5. Krystyna Pomorska, Russian Formalist Theory and Its Poctic Ambiance (The Hague, 1968), p. 18. 
ception of Roman Jakobson."' This, I suggest, is hardly "downgrading Shklovsky's role. ..."

Yet, the core of Mr. Sheldon's message lies elsewhere. His central thesis is that for some unaccountable reason the career of "one of the earliest and most outspoken defenders of creative freedom in the Soviet Union" was widely misconstrued in the West as "a series of surrenders which hastened or even precipitated the collapse of the Formalist movement." This viewwhich, inciclentally, I fail to recognize as my own ${ }^{7}$-is both inaccurate and unfair: it ignores a number of heterodox pronouncements which Shklovsky persisted in making during the period of his alleged retreats and accommodations. More important, it is insensitive to Shklovsky's "poetics of contradiction." Apparently, the "Western critics" failed to note that in nearly every instance a conciliatory statement on Shklovsky's part is accompanied by a gesture or a dictum which undercuts and effectively subverts it; in $\mathrm{Mr}$. Sheldon's phrase, they have overlooked the characteristic Shklovskian ploy - "the device of ostensible surrender."

The first case-in-point is the Western treatment of Zoo or Letters Not About Love (1923), a bizarre epistolary novel written during Shklovsky's brief and troubled Berlin exile. Again I appear to be the prime offender here since in Russian Formalism I wrote that in Zoo "Shklovsky had symbolically "surrendered' to the powers that be." (It may be worth noting that the word "surrenclered" is placed in quotes.) I was referring to the declaration in the book's concluding letter, addressed to the "All-Russian Central Executive Committee": "My youth is gone and so is my self-assurance. I raise my hand and surrender." 8

Mr. Sheldon maintains that the "subservience of this appeal" is countered by the last half of the letter "in which Shklovsky tells that the Turkish soldiers that surrendered to the Russians were massacred on the spot." $\mathrm{He}$ also reports that this portion of the letter was deleted from the 1964 edition of Zoo. He performs a useful service in calling our attention to the characteristically Shklovskian incongruity and to the recent Soviet censor's eagerness to remove it. Yet, can it be properly argued that this plea is effectively canceled by the Erzerum story? I am not persuaded that either the explicit repucliation of the speaker's past ("all that was has passed") or the gesture

6. Victor Erlich, Russian Formalism: History-Doctrinc, 3rd ed. (The Hague and Paris, 1969), p. 70.

7. At least one Western student of Formalism never spoke of a "series of surrenders" nor implied that anything Shklovsky felt impelled to do "hastened or precipitated the collapse of the Formalist movement." By 1930 the demise of Formalism was a foregone conclusion; Shklovsky's distinctive contribution was being the only Formalist spokesman to proclaim it publicly.

8. Erlich, Russian Formalism, p. 136. 
toward political loyalty ("The revolution transformed me; I cannot breathe without it.") is annulled by the censored passage, even if it is significantly modified by it. Also, in view of the linking sentence--"don't let the history of Erzerum repeat itself"-it might be fair to read the message of the uncensored version as: "I am not going to do it again. From now on I will behave, but please don't be mean or vindictive." In other words, one could describe the entire letter as an apology strongly tinged with apprehension. (It is a tribute to the nature of Shklovsky's poetics that this latter note was injected through the medium of a grisly anecdote.)

Having reinterpreted to his satisfaction the finale of $Z o o$, Professor Sheldon proceeds to demonstrate at length the essentially heterodox tenor of Shklovsky's 1926 volume Third Factory. I have no quarrel with him when he rejects Professor Piper's simplistic notion that Third Factory was "a repudiation of Formalism" or, more broadly, when he insists that Shklovsky did not throw in the sponge in 1923. (If after his return to Russia he seems to have steered clear of political opposition, he certainly did not eschew intellectual heresy.) But then $I$ have never suggested that $Z o o$ was, in fact, a turning point in Slkklovsky's career; I had called its finale a "symbolic" surrender, which antedated by seven years the substantive recantation, "A Monument to Scientific Error" (1930).

It is in reconstructing this ambiguous document that Professor Sheldon makes his most useful contribution. He is quite persuasive in arguing that Shklovsky's repudiation of "pure" Formalism was not necessarily insincerea point, incidentally, which I have come very close to making in my book and that a significant portion of the article was an attempt to salvage some of the late Formalist insights such as I. Tynianov's functional concept of literary evolution. He quite properly reminds us that Shklovsky managed to maintain a measure of intellectual self-esteem: rather than breathlessly declaring himself a Marxist, he pledged a thorough "studly of the Marxist method in its entirety."

All this is true as far as it goes: Shklovsky did not capitulate totally; he did not surrender abjectly. No wonder the Marxist-Leninist zealots found his recantation wanting: the Gelfands and the Gorbachevs, determined to humiliate as well as to disarm their opponents, would not have settled for anything less than total self-abasement. ${ }^{10}$ But to clescribe the actual thrust of the "Monument" simply as a "defense of the Formalist position as it had evolved during the twenties" is, to my mind, somewhat misleading.

Such a defense, reaching beyond the philosophical immaturity of Opoiaz,

9. "Some of it was sound and probably genuine self-criticism" (ibid., p. 136).

10. Parenthetically, I never said that Shklovsky's recantation was "abject," nor did I fail to record the witch-hunters' vociferous dissatisfaction with the "Monument." 
was offered two years earlier by Roman Jakobson and Iurii Tynianov. In a terse methodological statement published in Novyi lef, ${ }^{11}$ they repudiated the aesthetic separatism of the early Formalist writings and affirmed the interrelatedness of literature and other cultural domains in terms which we now clearly recognize as near-Structuralist. Of course, it would be unrealistic to expect of any theoretical pronouncement made by Shklovsky the rigor and precision that mark the Jakobson-Tynianov "theses." More relevantly, it would be unfair to clemand of an article published in Literaturnaia gazeta in 1930 the degree of intellectual independence that could still be achieved in a 1928 issue of Novyi lef. What I am suggesting is that the crucial difference between the two statements be clearly recognized. One was a sophisticated and, if I may use David Riesman's term, an "inner-directed" revision of the initial Formalist tenets. The other-even while managing to smuggle in indiviclual late-Formalist emphases-was predicated on the bankruptcy of Formalism as a coherent body of critical thought. ${ }^{12}$ By 1930 , the only permissible "ism" was Marxism.

In this connection, while Shklovsky deserves credit for refusing to accept Marx, as one would accept Christ at a revivalist meeting, I would hesitate to label his attitude toward Marxism "equivocal." The phrase "in its entirety" (see above, p. 114) strikes me not as a "puzzling qualification," but rather as a bit of not altogether unjustified self-criticism, a dig at the "sociological dilettantism" (Shklovsky's own phrase), or the do-it-yourself Marxism, of his 1928 study of $W$ ar and Peace. Furthermore, the statement "I am not declaring myself a Marxist, because one does not adhere to scientific methods. One masters them and one creates them" was more dignified than heterodox. It is true that in the Soviet Union official doctrine was, in fact, often treated as clogma. It is equally true that Marxism purports to be a scientific method, that is, something to be mastered rather than merely espoused. Shklovsky's stance failed to satisfy the bloody-minded hacks who were clamoring for the pound of Formalist flesh, but it was perfectly compatible with Marxist-Leninist etiquette. Thus, as I had previously indicated, ${ }^{13}$ in reply to his detractors Shklovsky found himself intoning that "in the last analysis it is the economic process which cletermines and reorganizes the literary series and the literary system." 14 Only three years earlier he criticized this position as "meta-

11. Roman Iakobson and Iurii Tynianov, "Problemy izucheniia literatury i iazyka," Novyi lcf, 1928, no. 12, pp. 36-37.

12. "As far as I am concerned, Formalism is a thing of the past. All that has remained from the Formal method is terminology ... and a number of technological observations. ..."

13. Erlich, Russian Formalism, p. 139.

14. Viktor B. Shklovskii, "Sukhoplavtsy, ili uravnenie s odnim neizvestnym," Literaturnaia gaseta, March 31, 1930, p. 2. 
physics." I cannot think offhand of any breakthrough in Soviet Marxist criticism of 1927-30 that would have persuaded Shklovsky of the validity or the meaningfulness of the above ritualistic formula.

To sum up, previous accounts, including my own, have underemphasized the hedged and ambiguous quality of Shklovsky's retreat, the extent to which it falls short of capitulation. Too much was being salvaged to justify such a label without major qualifications. By the same token, too much was being conceded under pressure for the act of surrender to be dismissed as an optical illusion, to be termed "ostensible."

Sheldon's challenge to the "prevailing view" that "Shklovsky adhered to the party line after 1930"15 rests in part on the memorable passage in Nadezhda Mandelstam's Hope Against Hope. During the dread 1930s the "only house [in Moscow] to which an outcast could always go" was the house of Viktor and Vasilisa Shklovsky. ${ }^{16}$ I take this testimonial very seriously indeed. Under the dehumanizing conditions of the Great Terror, hospitality to a proscribed friend was an act of moral fortitude and, it can be argued, also an act of loyalty to the values of an earlier, more humane age. And yet, personal decency, however admirable, however severely taxed, should not be confused with intellectual defiance.

It so happens that this distinction clearly emerges from the very memoir which contains the tribute to Shklovsky's unflagging kindness. Nadezhda Manclelstam, 180 pages earlier, refers to Zoo as "that sorry book in which he tearfully implores the victors to take him under their wing." ${ }^{7}$ This harsh judgment occurs, significantly, in one of the key sections of the book, the section decrying the moral "emptiness" of many early Soviet intellectuals, an emptiness which contributed to their premature capitulation to the regime. In Hope Abandoned, the matter is stated with characteristic starkness: "Uncertain of what we had to defend, we were only too quick to surrender." 18

The Western critic should not be too quick to echo this accusationor self-accusation-born from years of misery and travail. But he will do

15. Once again the nature of the alleged Western consensus is partly misrepresented -I for one never put it that way, though I may have implied that since 1930 Shklovsky was careful not to deviate too openly from the party line in ideologically charged areas. This, I submit, is still a tenable proposition: the painfully acquired habit of intellectual timidity, writ large in the 1953 collection of essays which Sheldon himself finds "dismal," has lingered on. The reminiscences about Mayakovsky in Zhili-byli (1961) hew more closely to the canonic view than the selectively candid memoirs of Ilya Ehrenburg's People, Years, Life.

16. Nadezhda Mandelstam, Hope Against Hopc: A Mcmoir, trans. Max Hayward (New York, 1970), p. 346.

17. Ibid., p. 166.

18. Nadezhda Mandelstam, Hope Abandoned, trans. Max Hayward (New York, 1974), p. 164. 
well to heed the pointed reminder that through the 1920 s the Soviet intellectual's resistance to the rising tide of authoritarianism was eroded not only by outside pressures but also by inward confusion, by mounting uncertainty as to the "timeliness" and historical viability of political and cultural freedom.

Such disarray-a corollary, one suspects, of the sudden collapse of unexamined ideological assumptions-is already apparent in Shklovsky's first and most appealing memoir, A Sentimental Journey (1923). It seems that during one of his most dangerous Civil War assignments Shklovsky found solace in teaching the wounded soldiers fractions. "In the midst of all this misery ... which I did not understand . . . it is very reassuring to say calmly: the larger the numerator, the larger the fraction; the larger the denominator, the smaller the fraction. . . That is a sure thing. It is the only sure thing I know" [italics mine].$^{19}$ In Third Factory, this honest confusion assumes the form of a full-blown methodological and spiritual crisis. Professor Sheldon is unhappy about my reference to a "malaise" which pervades the volume. He prefers to speak of "anguish"-a perfectly understandable reaction, he insists, both to Shklovsky's personal predicament and the imminent threat to creative freedom heralded by the Party Resolution of 1925 .

That, in the mid-1920s, Shklovsky and his associates had a great deal to worry about is scarcely news to me. But the "pressures generated by these developments" do not fully account for the tone of Third Factory, for the bewildering pattern of shuttling between spirited defense of creative freedom and meanderings about the advantages or the historic necessity of "unfreedom," and for gnawing doubts about the role played by Opoiaz ("Were we meant to be the seed or the stalk ?"). What is at issue here, I would suggest, is more than a stratagem, or more than another instance of Shklovsky's "poetics of contradiction." It is genuine ambivalence enacted, now candidly, now cagily, in full view of the Russian reading public. I agree that at its heretical best Third Factory is vintage Shklovsky. Yet considered in toto this miscellany is neither the "second of Shklovsky's surrenders," nor simply "a passionate defense of Formalism." Its uneasy ambiance is a long way away from the cocky self-assurance of Shklovsky's Khod konia (1923) or the fiery intransigence of one of his most brilliant disciples, Lev Lunts. ${ }^{20}$

It would be presumptuous on the part of those who have not experienced the cataclysmic upheavals or the soul-destroying pressures that have shaped Soviet culture to adopt a superior or a scornful stance toward the modes of

19. Viktor Shklovsky, A Scutimcntal Journcy: Mcmoirs, 1917-1922, trans. Richard Sheldon (Ithaca and London, 1970), p. 211.

20. I am referring of course to Lunts's often quoted credo "Why we are Serapion Brothers" (Litcraturnye zapiski, no. 3 [1922], pp. 30-31) which became the manifesto of that remarkable grouping. 
accommodation and survival elected by some of "the children of Russia's terrible years" (A. Blok). But there is no need to play down the cost of such survival. There is no need to construe what has been, to echo a Soviet euphemism, a "complex path" (slozhnyi put') as a consistent, if at times cunning, defense of creative freedom. Finally a word about 1930. I may have been unfair to Viktor Borisovich by not acknowledging explicitly how difficult it was to attempt to talk sense about literature in the atmosphere of intellectual lynching parties. Yet I must confess to a certain rigidity of taste: in a situation where it becomes necessary to adopt the enemy's terms of reference in order to keep talking, the silence of a Boris Eikhenbaum still appears to me a preferable option to the double-edged loquacity of a Viktor Shklovsky. 